\title{
Article \\ Effects of Reflectance of Backsheets and Spacing between Cells on Photovoltaic Modules
}

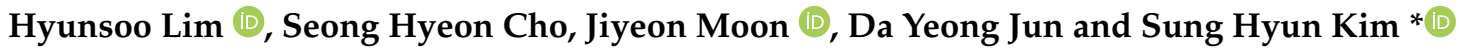

check for updates

Citation: Lim, H.; Cho, S.H.; Moon, J.; Jun, D.Y.; Kim, S.H. Effects of Reflectance of Backsheets and Spacing between Cells on Photovoltaic Modules. Appl. Sci. 2022, 12, 443. https://doi.org/ 10.3390/app12010443

Academic Editor: Eun-Chel Cho

Received: 2 December 2021

Accepted: 29 December 2021

Published: 3 January 2022

Publisher's Note: MDPI stays neutral with regard to jurisdictional claims in published maps and institutional affiliations.

Copyright: (c) 2022 by the authors. Licensee MDPI, Basel, Switzerland. This article is an open access article distributed under the terms and conditions of the Creative Commons Attribution (CC BY) license (https:// creativecommons.org/licenses/by/ $4.0 /)$.
New \& Renewable Energy Research Center, Korea Electronics Technology Institute (KETI), 25, Saenari-ro, Bundang-gu, Seongnam-si 13509, Gyeonggi-do, Korea; hyunsoo.lim@keti.re.kr (H.L.); csh7232@keti.re.kr (S.H.C.); letsbounce@keti.re.kr (J.M.); jundy0917@keti.re.kr (D.Y.J.)

* Correspondence: shkim@keti.re.kr

\begin{abstract}
In the photovoltaic (PV) module manufacturing process, cell-to-module (CTM) loss is inevitably caused by the optical loss, and it generally leads to the output power loss of about 2 3\%. It is known that the CTM loss rate can be reduced by increasing the reflectance of a backsheet and reflective area through widening spaces between the PV cell strings. In this study, multi-busbars (MBB) and shingled PV cells were connected in series, and a mini-module composed of four cells was fabricated with a white and black backsheet to investigate the effects of reflectance of backsheets and space between the PV cells. Moreover, the MBB modules with cell gap spaces of $0.5 \mathrm{~mm}, 1.5 \mathrm{~mm}$, and $2.5 \mathrm{~mm}$ were demonstrated with fixed $3 \mathrm{~mm}$ spaces between the strings. The shingled modules with varying spaces from $2 \mathrm{~mm}$ to $6 \mathrm{~mm}$ were also tested, and our results show that spacing between PV cells and strings should be well-balanced to minimize the CTM loss to maximize the output power (efficiency).
\end{abstract}

Keywords: photovoltaic modules; multi-busbar modules; shingled modules; backsheet reflectance; spaces between PV cells; CTM loss; output power

\section{Introduction}

Photovoltaic technology for PV cells and their modules has achieved remarkable advances and development to enhance the output power of PV modules [1]. Consequently, many efforts devoted to enhancing cell efficiency has led to the development of new structural silicon-based PV cells, such as the tunnel oxide passivated contact (TOPCon) cell [2-9], passivated emitter and rear cell (PERC) [10-15], heterojunction (HJT) cell [16-22], and so on. With respect to modulization technology, various modulization technologies have been developed, such as shingled [23-26] and MBB [27-29] modulization. In general, modulization technology refers to the technology of connecting PV cells without CTM loss, so-called "string". Both research and industrial fields have the common goal to reduce the space between cells to obtain as high a cell-to-glass (C2G) area ratio (cell area/glass area) as possible. Apart from the effect of the $\mathrm{C} 2 \mathrm{G}$ ratio, reflectance is also another crucial factor in achieving high energy efficiency. Reducing the space between cells (or increasing the C2G ratio) leads to a decrease in the reflectance of solar light by backsheets. Some reports state that the reflectance by backsheets is much more efficient to fabricate PV modules with high energy efficiency $[30,31]$.

Few reports claim the importance of the balance between the $\mathrm{C} 2 \mathrm{G}$ ratio and the reflectance of backsheets for highly efficient PV modules [32]. It suggests that most reports focused on a single side of achieving either a high C2G module or highly reflective backsheet. In this report, we investigated the effects of the reflectance of backsheets, the space between PV cells in the modules, and their balance. In detail, shingled and MBB PV modules were fabricated and different spaces from $0.5 \mathrm{~mm}$ to $6 \mathrm{~mm}$ were incorporated. Various backsheets, such as white back sheets (W), black backsheets (B), and hybrid-type backsheets (W-B) were also demonstrated to check reflectance effects. The results show 
the balance is important rather than high $\mathrm{C} 2 \mathrm{G}$ and high reflectance. This may open a new direction of module technology for gaining optimized PV efficiency.

\section{Materials and Methods}

\subsection{Materials}

M3-size single crystalline silicon (Si) based PERC-type PV cells with $21.2 \%$ efficiency were received from a company (Shinsung E\&G, Seongnam-si, Korea) and used without any additional treatment. Lead-tin (Sn60Pb40, KOSWIRE, Flowery Branch, GA, USA) wires with $0.26 \mathrm{~mm}$ diameter were used for string fabrication of MBB modules. Flux (920CXF, KESTER) was used for removing the oxide layer on the wires and PV cells. Electrically conductive adhesive (ECA) (DS-0860A, DAEJOO, Korea) was used. Glasses (Low Iron Float Glass, Nuri-Corporation, Seongnam-si, Korea) with 3.2 T were purchased for the encapsulation process. Ethylene-vinyl acetate (EVA) films (HEP-02T, HANWHA, Seoul, Korea) with a transmittance of $91.08 \%$ were used. The white backsheets and black backsheets were purchased from the SFC Corporation (Seoul, Korea). Home-made equipment was exploited for the shingled and MBB PV modularization process.

\subsection{Methods}

Shingled cells were cut into 5 cut cells using the laser-cut process. For the shingled string process, ECA was screen-printed onto the cut shingled cells, and they were bonded in series, and then cured at $170{ }^{\circ} \mathrm{C}$ for $60 \mathrm{~s}$. MBB cells with 12 busbars wwere cut in half. For the MBB string process, $\mathrm{PV}$ cells were soldered by applying flux and oven-dried wire at $100{ }^{\circ} \mathrm{C}$ for $15 \mathrm{~s}$ and irradiating an IR lamp at $180{ }^{\circ} \mathrm{C}$ in a tabber and stringer for $3 \mathrm{~s}$. Both shingled and MBB strings were laminated at $160^{\circ} \mathrm{C}$ for $23 \mathrm{~min}$ in various types, as shown in Figure 1, using the same glasses and EVA films. Figure 1 shows the illustrations of the fabricated MBB and shingled PV modules with white (Figure 1a,d), black (Figure 1b,e), and white-black (W-B) hybrid backsheets (Figure 1c,f). For MBB PV modules (Figure 1a-c), the vertical spaces between PV cells were controlled with $0.5,1.5,2.5 \mathrm{~mm}$ gaps. The horizontal spaces were kept constant at a $3 \mathrm{~mm}$ gap. White and black backsheets covered the entire PV modules (Figure 1a,b,d,e), black backsheets covered only borders for PV modules using W-B hybrid-type backsheets (Figure 1c,f).

a

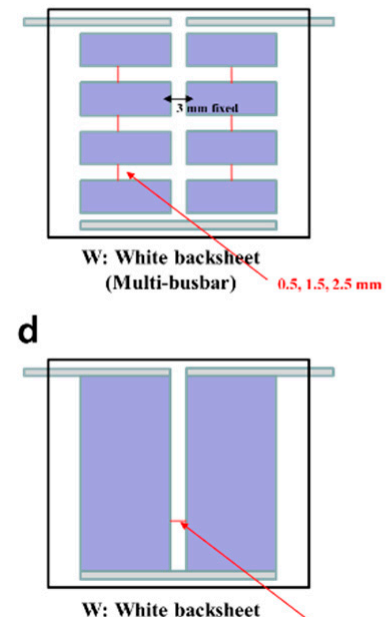

(Shingled)
White backs b

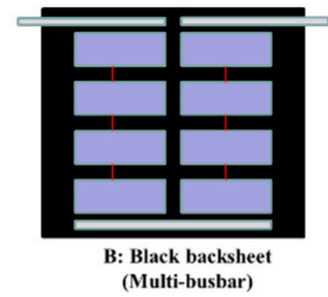

e

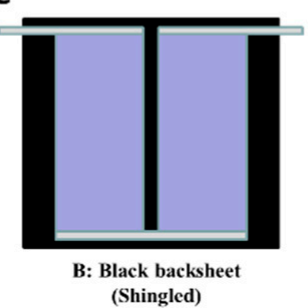

c

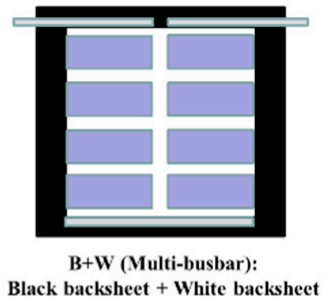

f

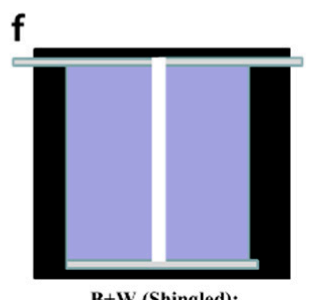

Black backsheet + White backsheet

Figure 1. The illustrations of the fabricated MBB $(\mathbf{a}-\mathbf{c})$ and shingled $(\mathbf{d}-\mathbf{f})$ modules with white, black, and white-black hybrid-type backsheets. 


\section{Results}

\subsection{Comparison of Backsheets}

Figure 2 shows the film reflectance graph of the white and black backsheets used in this experiment and Supplementary Materials Figure S1 displays the illustrated explanation of the concept. The average of the white backsheet reflectance was $85.39 \%$ in the range of 300 to1200 nm and the peak was $96.67 \%$ at $433 \mathrm{~nm}$. The average of the black backsheet reflectance was $42.43 \%$ in the range of 300 to $1200 \mathrm{~nm}$ and the peak was $93.15 \%$ at $986 \mathrm{~nm}$. The average reflectance of the black backsheet was more or less than half of that of the white backsheet. The black backsheet reflected the IR region, which is 750-1200 nm, while the white backsheet reflected the visible and IR region, which is 380-1200 nm. The result shows that black backsheets absorb visible light and how much reflection of visible light affects module efficiency.

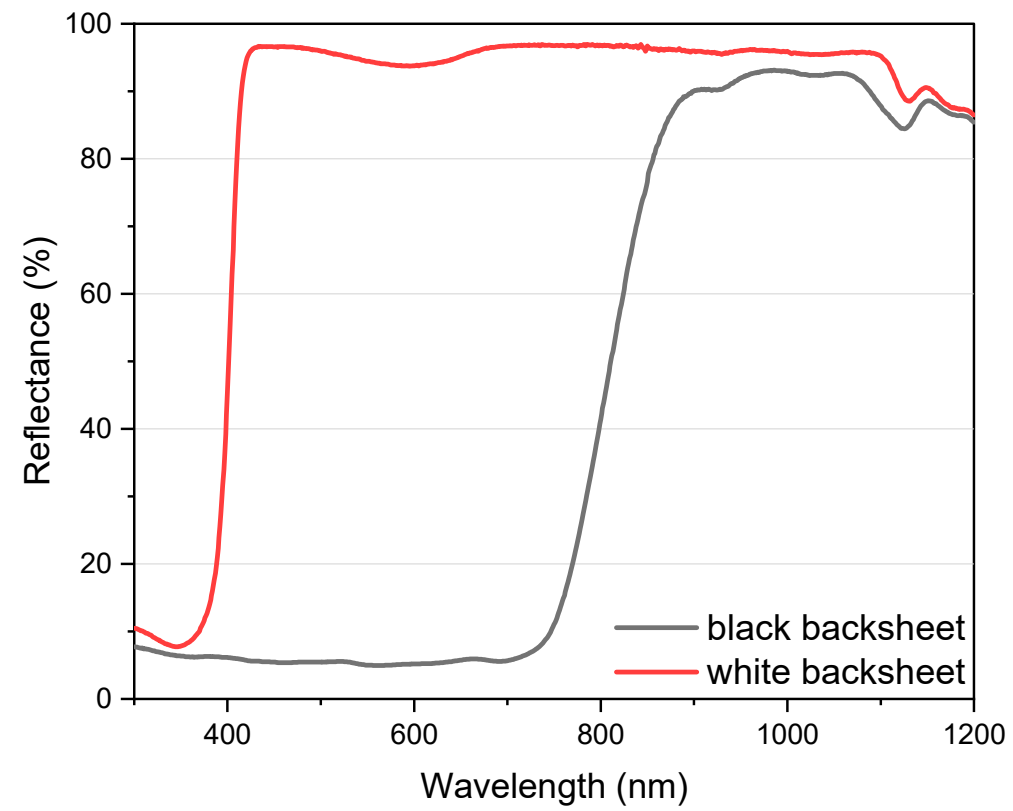

Figure 2. The reflectance of white and black backsheets in the vis-near-infrared (IR) range.

\subsection{Comparison of Backsheets for MBB PV Modules}

Figure $3 a, b$ show the short-circuit current $\left(\mathrm{I}_{\mathrm{sc}}\right)$ and maximum power $\left(\mathrm{P}_{\max }\right)$ of the MBB PV modules by various cell spaces, 0.5 (black line), 1.5 (red line), and $2.5 \mathrm{~mm}$ (blue line), respectively. In Figure $3 \mathrm{a}, \mathrm{I}_{\mathrm{sc}}$ increased as the area of the white backsheet increased $(\mathrm{B}<\mathrm{B}-\mathrm{W}<\mathrm{W})$. The result indicates the reflected visible light affects $\mathrm{I}_{\mathrm{Sc}}$ leading to an increase in PV module efficiency. The difference in $\mathrm{I}_{\mathrm{sc}}$ was about $0.1 \mathrm{~A}$ for all PV modules, regardless of the gap spaces. Interestingly, the PV module with the broadest gap space $(2.5 \mathrm{~mm})$, blue line in Figure 3a, exhibited the highest $\mathrm{I}_{\mathrm{sc}}$ among the three PV modules. It reveals the optical gain by white backsheet results in an increase in $\mathrm{I}_{\mathrm{Sc}}$. For $\mathrm{P}_{\max }$ in Figure $3 b$, the same tendency was observed $(B<B-W<W)$. The increase in Pmax using $2.5 \mathrm{~mm}$ gap space was about $1.4 \%$ compared to that with $0.5 \mathrm{~mm}$ gap space. However, the PV module with $2.5 \mathrm{~mm}$ with B and B-W backsheet did not show the highest $P_{\max }$ because its open-circuit voltage $\left(\mathrm{V}_{\mathrm{OC}}\right)$ value was not as high as that of other values. It seems that it can be influenced by the variation of $V_{o c}$ because $V_{o c}$ variation does not show any trend as shown in Tables A1-A3 in Appendix A. 

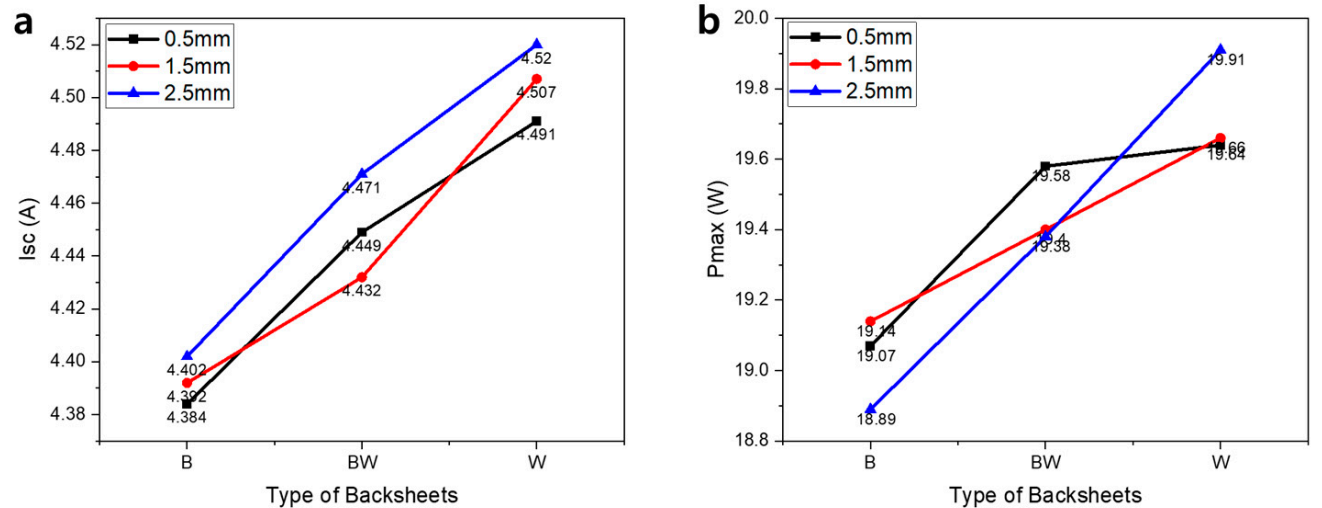

Figure 3. (a) The short-circuit current $\left(\mathrm{I}_{\mathrm{sc}}\right)$ and $(\mathbf{b})$ maximum power $\left(\mathrm{P}_{\max }\right)$ of the MBB PV modules with white, black, and W-B hybrid backsheets and various cell spaces $(0.5,1.5,2.5 \mathrm{~mm})$.

\subsection{Comparison of Backsheets for Shingled PV Modules}

Figure $4 \mathrm{a}, \mathrm{b}$ show the short-circuit current $\left(\mathrm{I}_{\mathrm{sc}}\right)$ and maximum power $\left(\mathrm{P}_{\max }\right)$ of the shingled PV modules by various cell spaces, 2 (black line) and $6 \mathrm{~mm}$ (red line), respectively. Figure 4a shows increasing the area of the white backsheet led to a higher $\mathrm{I}_{\mathrm{sc}}(\mathrm{B}<\mathrm{B}-\mathrm{W}<\mathrm{W})$ as demonstrated by the MBB PV module result. A wider gap $(6 \mathrm{~mm})$ resulted in higher $\mathrm{I}_{\mathrm{sc}}$. The shingled PV modules with a black backsheet and different gap spaces were almost identical, while that with a white backsheet showed a $1.1 \% \mathrm{I}_{\mathrm{sc}}$ increase when a $6 \mathrm{~mm}$ gap space was incorporated. In terms of power, $\mathrm{P}_{\max }$ sloped upward as the area of the white backsheet became larger. The increase should originate from large $\mathrm{I}_{\mathrm{sc}}$, not from $\mathrm{V}_{\mathrm{oc}}$, and the percentage of the difference was $2.1 \%$. The detailed experimental data are summarized in Tables A4 and A5 in Appendix A.
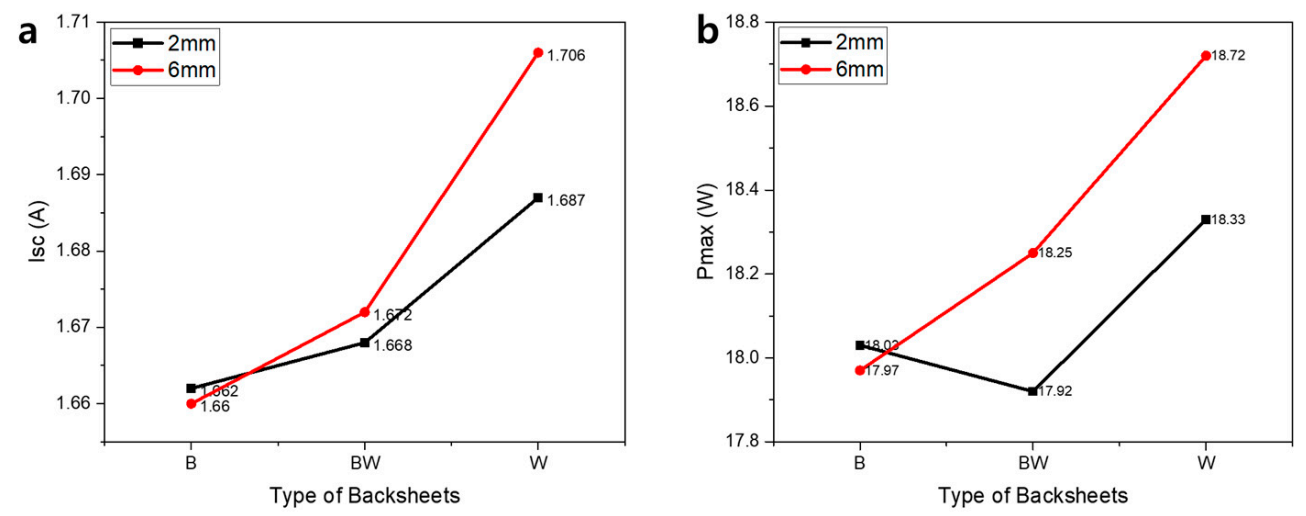

Figure 4. (a) The short-circuit current $\left(\mathrm{I}_{\mathrm{sc}}\right)$ and $(\mathrm{b})$ maximum power $\left(\mathrm{P}_{\max }\right)$ of the shingled PV modules with white, black, and W-B hybrid backsheets and various cell spaces (2 and $6 \mathrm{~mm}$ ).

\section{Discussion}

Experimental results obtained by using different backsheets and gap spaces between PV cells concluded that those two factors are important to improve PV module efficiency. It indicated that wide gap spaces improve both MBB and shingled PV module efficiencies. As discussed in Section 1 Introduction, however, one should note that incorporating wide gap spaces use space where more PV cells could be placed. Balancing between the appropriate gap spaces and the number of cells is, therefore, the most critical factor.

When gap space was $2.5 \mathrm{~mm}$ for the MBB PV module and $6 \mathrm{~mm}$ for the shingled PV module, the increase in $\mathrm{P}_{\max }$ was $1.4 \%$ and $2.1 \%$, respectively. In general, a couple more cells were needed to improve about $1-2 \%$ of power in a certain area. This indicates that the number of PV cells required to achieve a desired power or efficiency can be reduced by incorporating gap spaces, hence allowing for a reduction in PV module cost. 


\section{Conclusions}

In conclusion, the effects of gap spaces between PV cells and backsheets were investigated. For the study of gap spaces, broad gaps of $2.5 \mathrm{~mm}$ and $6 \mathrm{~mm}$ for the MBB and shingled module, respectively, improved $\mathrm{I}_{\mathrm{sc}} \mathrm{s}$ leading to an increase in PV module power and efficiency. In terms of backsheet, the white backsheet showed superior performances compared to the black and B-W hybrid backsheets. This is because the white backsheet reflects visible light and the reflected light is absorbed into PV cells again. The results suggest that broad gap spaces and white backsheet enhance module efficiency. For commercial production, however, too broad a gap space reduces space for PV cells and leads to fewer PV cells incorporated into PV modules. Therefore, the balance between the number of PV cells and gap spaces with white backsheet is substantially crucial to obtain high PV module efficiency.

Supplementary Materials: The following are available online at https:/ /www.mdpi.com/article/10 $.3390 /$ app12010443/s1, Figure S1: Illustration of the light pathway irradiated from the front glass. It is absorbed by PV cells.

Author Contributions: Conceptualization, H.L. and S.H.K.; methodology, H.L. and S.H.C.; software, S.H.C.; validation, J.M. and D.Y.J.; formal analysis, H.L.; investigation, S.H.C.; resources, H.L.; data curation, H.L.; writing—original draft preparation, H.L.; writing—review and editing, H.L. and S.H.K.; visualization, H.L.; supervision, S.H.K.; project administration, S.H.K.; funding acquisition, S.H.K. All authors have read and agreed to the published version of the manuscript.

Funding: This work was supported by the New \& Renewable Energy of the Korea Institute of Energy Technology Evaluation and Planning (KETEP) granted financial resources from the Ministry of Trade, Industry \& Energy, Republic of Korea (No. 20213030010240\& 20213030010290).

Institutional Review Board Statement: Not applicable.

Informed Consent Statement: Not applicable.

Data Availability Statement: Not applicable.

Conflicts of Interest: The authors declare no conflict of interest.

\section{Appendix A}

Table A1. The summary of MBB module operating test with various backsheets with $0.5 \mathrm{~mm}$ gap space.

\begin{tabular}{cccc}
\hline $\begin{array}{c}\text { Space } \\
(\mathbf{0 . 5} \mathbf{~} \mathbf{m})\end{array}$ & $\mathbf{B}$ & $\mathbf{B}+\mathbf{W}$ & $\mathbf{W}$ \\
\hline $\mathrm{I}_{\mathrm{sc}}(\mathrm{A})$ & 4.384 & 4.449 & 4.491 \\
$\mathrm{~V}_{\mathrm{oc}}(\mathrm{V})$ & 5.386 & 5.434 & 5.402 \\
$\mathrm{P}_{\mathrm{m}}(\mathrm{W})$ & 19.07 & 19.58 & 19.64 \\
$\mathrm{I}_{\mathrm{pm}}(\mathrm{A})$ & 4.18 & 4.251 & 4.296 \\
$\mathrm{~V}_{\mathrm{pm}}(\mathrm{V})$ & 4.561 & 4.607 & 4.572 \\
$\mathrm{FF}(\%)$ & 80.76 & 81.02 & 80.95 \\
\hline
\end{tabular}

Table A2. The summary of MBB module operating test with various backsheets with $1.5 \mathrm{~mm}$ gap space.

\begin{tabular}{cccc}
\hline $\begin{array}{c}\text { Space } \\
\mathbf{( 1 . 5} \mathbf{~ m m})\end{array}$ & B & B $+\mathbf{W}$ & W \\
\hline $\mathrm{I}_{\mathrm{sc}}(\mathrm{A})$ & 4.392 & 4.432 & 4.507 \\
$\mathrm{~V}_{\mathrm{oc}}(\mathrm{V})$ & 5.398 & 5.389 & 5.406 \\
$\mathrm{P}_{\mathrm{m}}(\mathrm{W})$ & 19.14 & 19.4 & 19.66 \\
$\mathrm{I}_{\mathrm{pm}}(\mathrm{A})$ & 4.196 & 4.248 & 4.296 \\
$\mathrm{~V}_{\mathrm{pm}}(\mathrm{V})$ & 4.561 & 4.567 & 4.576 \\
$\mathrm{FF}(\%)$ & 80.72 & 81.21 & 80.69 \\
\hline
\end{tabular}


Table A3. The summary of MBB module operating test with various backsheets with $2.5 \mathrm{~mm}$ gap space.

\begin{tabular}{cccc}
\hline $\begin{array}{c}\text { Space } \\
(2.5 \mathbf{~ m m})\end{array}$ & B & $\mathbf{B}+\mathbf{W}$ & $\mathbf{W}$ \\
\hline $\mathrm{I}_{\mathrm{sc}}(\mathrm{A})$ & 4.402 & 4.471 & 4.520 \\
$\mathrm{~V}_{\mathrm{oc}}(\mathrm{V})$ & 5.352 & 5.384 & 5.405 \\
$\mathrm{P}_{\mathrm{m}}(\mathrm{W})$ & 18.89 & 19.38 & 19.91 \\
$\mathrm{I}_{\mathrm{pm}}(\mathrm{A})$ & 4.188 & 4.262 & 4.351 \\
\hline $\mathrm{V}_{\mathrm{pm}}(\mathrm{V})$ & 4.510 & 4.546 & 4.576 \\
$\mathrm{FF}(\%)$ & 80.16 & 80.50 & 81.50 \\
\hline
\end{tabular}

Table A4. The summary of shingled module operating test with various backsheets with $2 \mathrm{~mm}$ gap space.

\begin{tabular}{cccc}
\hline $\begin{array}{c}\text { Space } \\
(\mathbf{2} \mathbf{~ m m})\end{array}$ & B & B $+\mathbf{W}$ & W \\
\hline $\mathrm{I}_{\mathrm{sc}}(\mathrm{A})$ & 1.662 & 1.668 & 1.687 \\
$\mathrm{~V}_{\mathrm{oc}}(\mathrm{V})$ & 13.54 & 13.41 & 13.44 \\
$\mathrm{P}_{\mathrm{m}}(\mathrm{W})$ & 18.03 & 17.92 & 18.33 \\
$\mathrm{I}_{\mathrm{pm}}(\mathrm{A})$ & 1.580 & 1.587 & 1.616 \\
$\mathrm{~V}_{\mathrm{pm}}(\mathrm{V})$ & 11.41 & 11.29 & 11.34 \\
$\mathrm{FF}(\%)$ & 80.09 & 80.15 & 80.85 \\
\hline
\end{tabular}

Table A5. The summary of shingled module operating test with various backsheets with $6 \mathrm{~mm}$ gap space.

\begin{tabular}{cccc}
\hline $\begin{array}{c}\text { Space } \\
\mathbf{( 6 ~} \mathbf{~ m m})\end{array}$ & B & B + W & W \\
\hline $\mathrm{I}_{\mathrm{sc}}(\mathrm{A})$ & 1.66 & 1.672 & 1.706 \\
$\mathrm{~V}_{\mathrm{oc}}(\mathrm{V})$ & 13.49 & 13.58 & 13.61 \\
$\mathrm{P}_{\mathrm{m}}(\mathrm{W})$ & 17.97 & 18.25 & 18.72 \\
$\mathrm{I}_{\mathrm{pm}}(\mathrm{A})$ & 1.576 & 1.589 & 1.628 \\
$\mathrm{~V}_{\mathrm{pm}}(\mathrm{V})$ & 11.41 & 11.49 & 11.50 \\
$\mathrm{FF}(\%)$ & 80.25 & 80.51 & 80.60 \\
\hline
\end{tabular}

\section{References}

1. Ajayan, J.; Nirmal, D.; Mohankumar, P.; Saravanan, M.; Jagadesh, M.; Arivazhagan, L. A review of photovoltaic performance of organic/inorganic solar cells for future renewable and sustainable energy technologies. Superlattices Microstruct. 2020, 143, 106549. [CrossRef]

2. Kafle, B.; Goraya, B.S.; Mack, S.; Feldmann, F.; Nold, S.; Rentsch, J. TOPCon-Technology options for cost efficient industrial manufacturing. Sol. Energy Mater. Sol. Cells 2021, 227, 111100. [CrossRef]

3. Yousuf, H.; Khokhar, M.Q.; Chowdhury, S.; Pham, D.P.; Kim, Y.; Ju, M.; Cho, Y.; Cho, E.-C.; Yi, J. A Review on TOPCon Solar Cell Technology. Curr. Photovolt. Res. 2021, 9, 75-83.

4. Wang, Q.; Wu, W.; Li, Y.; Yuan, L.; Yang, S.; Sun, Y.; Yang, S.; Zhang, Q.; Cao, Y.; Qu, H.; et al. Impact of boron doping on electrical performance and efficiency of n-TOPCon solar cell. Sol. Energy 2021, 227, 273-291. [CrossRef]

5. Anand, N.; Kale, P. Optimization of TOPCon Structured Solar Cell Using AFORS-HET. Trans. Electr. Electron. Mater. 2021, 22, 160-166. [CrossRef]

6. Feldmann, F.; Simon, M.; Bivour, M.; Reichel, C.; Hermle, M.; Glunz, S.W. Efficient carrier-selective p- and n-contacts for Si solar cells. Sol. Energy Mater. Sol. Cells 2014, 131, 100-104. [CrossRef]

7. Feldmann, F.; Bivour, M.; Reichel, C.; Steinkemper, H.; Hermle, M.; Glunz, S.W. Tunnel oxide passivated contacts as an alternative to partial rear contacts. Sol. Energy Mater. Sol. Cells 2014, 131, 46-50. [CrossRef]

8. Richter, A.; Benick, J.; Müller, R.; Feldmann, F.; Reichel, C.; Hermle, M.; Glunz, S.W. Tunnel oxide passivating electron contacts as full-area rear emitter of high-efficiency p-type silicon solar cells. Prog. Photovolt. Res. Appl. 2018, 26, 579-586. [CrossRef]

9. Gao, T.; Yang, Q.; Guo, X.; Huang, Y.; Zhang, Z.; Wang, Z.; Liao, M.; Shou, C.; Zeng, Y.; Yana, B.; et al. An industrially viable TOPCon structure with both ultra-thin SiOx and n+-poly-Si processed by PECVD for p-type c-Si solar cells. Sol. Energy Mater. Sol. Cells 2019, 200, 109926. [CrossRef]

10. Kim, K.; Lee, S.; Chowdhury, S.; Yi, J. A Brief Review of Passivation Materials and Process for High Efficiency PERC Solar Cell. Trans. Electr. Electron. Mater. 2021, 1-5. [CrossRef] 
11. Rain, G.; Sinha, S. A simulation study to evaluate and compare monofacial Vs bifacial PERC PV cells and the effect of albedo on bifacial performance. Mater. Today Proc. 2021, 46, 5242-5247. [CrossRef]

12. Dullweber, T.; Schmidt, J. Industrial Silicon Solar Cells Applying the Passivated Emitter and Rear Cell (PERC) Concept-A Review. IEEE J. Photovolt. 2016, 6, 1366-1381. [CrossRef]

13. Tong, R.; Zhang, W.; Ke, X.; Liu, Z. Influence of surface structure on the performance of mono-like Si PERC solar cell. Mater. Sci. Semicond. Process 2021, 126, 105662. [CrossRef]

14. Green, M.A. The Passivated Emitter and Rear Cell (PERC): From conception to mass production. Sol. Energy Mater. Sol. Cells 2015, 143, 190-197. [CrossRef]

15. Blakers, A. Development of the PERC Solar Cell. IEEE J. Photovolt. 2019, 9, 629-635. [CrossRef]

16. Panigrahi, J.; Komarala, V.K. Progress on the intrinsic a-Si:H films for interface passivation of silicon heterojunction solar cells: A review. J. Non. Cryst. Solids 2021, 574, 121166. [CrossRef]

17. Xia, Y.; Dai, D. Review on applications of PEDOTs and PEDOT:PSS in perovskite solar cells. J. Mater. Sci. Mater. 2021, 32, 12746-12757. [CrossRef]

18. Qu, X.; He, Y.; Qu, M.; Ruan, T.; Chu, F.; Zheng, Z.; Ma, Y.; Chen, Y.; Ru, X.; Xu, X.; et al. Identification of embedded nanotwins at c-Si/a-Si:H interface limiting the performance of high-efficiency silicon heterojunction solar cells. Nat. Energy 2021, 6, 194-202. [CrossRef]

19. Park, H.; Ju, M.; Khokhar, M.Q.; Cho, E.-C.; Kim, Y.; Cho, Y.; Yi, J. Surface Modifications for Light Trapping in Silicon Heterojunction Solar Cells: A Brief Review. Trans. Electr. Electron. Mater. 2020, 21, 349-354. [CrossRef]

20. Masuko, K.; Shigematsu, M.; Hashiguchi, T.; Fujishima, D.; Kai, M.; Yoshimura, N.; Yamaguchi, T.; Ichihashi, Y.; Mishima, T.; Matsubara, N.; et al. Achievement of More Than 25\% Conversion Efficiency With Crystalline Silicon Heterojunction Solar Cell. IEEE J. Photovolt. 2014, 4, 1433-1435. [CrossRef]

21. Wolf, S.D.; Descoeudres, A.; Holman, Z.C.; Ballif, C. High-efficiency Silicon Heterojunction Solar Cells: A Review. Green 2012, 2, 7-24. [CrossRef]

22. Jensen, N.; Hausner, R.M.; Bergmann, R.B.; Werner, J.H.; Rau, U. Optimization and Characterization of Amorphous/Crystalline Silicon Heterojunction Solar Cells. Prog. Photovolt: Res. Appl. 2002, 10, 1-13. [CrossRef]

23. Mittag, M.; Zech, T.; Wiese, M.; Bläsi, D.; Ebert, M.; Wirth, H. Cell-to-Module (CTM) Analysis for Photovoltaic Modules with Shingled Solar Cells. In Proceedings of the 2017 IEEE 44th Photovoltaic Specialist Conference (PVSC), Washington, DC, USA, 25-30 June 2017; pp. 1531-1536.

24. Jun, D.; Son, H.; Moon, J.; Cho, S.; Kim, S.H. A Study on Correlation Peel Strength and the Efficiency of Shingled Modules According to Curing Condition of Electrically Conductive Adhesives. Curr. Photovolt. Res. 2021, 9, 31-35.

25. Kim, J.; Kim, J.; Jeong, C.; Choi, W.; Lee, J. Study on Shingled String Interconnection for High Power Solar Module. J. Korean Inst. Electr. Electron. Mater. Eng. 2021, 34, 449-453.

26. Oh, W.; Park, J.; Dimitrijev, S.; Kim, E.K.; Park, Y.S.; Lee, J. Metallization of crystalline silicon solar cells for shingled photovoltaic module application. Sol. Energy 2020, 195, 527-535. [CrossRef]

27. Braun, S.; Hahn, G.; Nissler, R.; Pönisch, C.; Habermann, D. The multi-busbar design: An overview. Energy Procedia 2013, 43 , 86-92. [CrossRef]

28. Park, J.E.; Choi, W.S.; Lim, D. Cell/Module Integration Technology with Wire-Embedded EVA Sheet. Appl. Sci. 2021, 11, 4170. [CrossRef]

29. Jiang, Y.; Huang, G.; Zhuang, H.; Sun, G.; Li, J. Energy simulation of p-PERC bifacial modules based on different installation environment. IOP Conf. Ser. Earth Environ. Sci. 2021, 675, 012188. [CrossRef]

30. Kim, N.; Lee, S.; Zhao, X.G.; Kim, D.; Oh, C.; Kang, H. Reflection and durability study of different types of backsheetsand their impact on c-Si PV module perform. Sol. Energy Mater. Sol. Cells 2016, 146, 91-98. [CrossRef]

31. Vogta, M.R.; Holsta, H.; Schulte-Huxela, H.; Blankemeyera, S.; Wittecka, R.; Bujardb, P.; Kuesc, J.-B.; Schinked, C.; Bothea, K.; Köntgesa, M.; et al. PV module current gains due to structured backsheets. Energy Procedia 2017, 124, 495-503. [CrossRef]

32. Saw, M.H.; Khoo, Y.S.; Singh, J.P.; Wang, Y. Cell-to-module optical loss/gain analysis for various photovoltaic module materials through systematic characterization. Jpn. J. Appl. Phys. 2017, 56, 08MD03. [CrossRef] 